\title{
Isolation and biochemical characterization of probiotic bacteria obtained from yogurt samples of Rajshahi and Chittagong divisions of Bangladesh and their antimicrobial activity against enteric pathogens
}

\author{
K.M. Hossain ${ }^{1 *}$, P. Barai ${ }^{2}$, S.M.M. Rahman ${ }^{1}$, M.F.Al-Mazid ${ }^{2}$, M.S.Gazi ${ }^{2}$ and M.A. Jalil ${ }^{2}$ \\ ${ }^{1}$ Biotechnology and Genetic Engineering Discipline, Life Science School, Khulna University, \\ Khulna-9208, Bangladesh.
}

\begin{abstract}
Probiotics are generally live microorganisms which exert beneficial effects on human and animal health by improving the gastrointestinal microflora. Isolation and proper identification of probiotic bacteria are very much important for safe use in food and feed industry. With this perceptive, the aim of the present study was the isolation of probiotic bacteria and their biochemical characterization. In this study, ten probiotic Lactobacillus spp. was isolated and according to their morphological, physiological and biochemical assay, it was observed that all the isolated bacteria were rod shaped, gram positive, catalase negative, non-motile and coagulase positive which are an indicator of typical probiotic bacteria. Carbohydrate fermentation pattern and growth against inhibitory substances viz. $\mathrm{pH} 3.0,0.3 \%$ bile, $0.1-0.4 \%$ phenol and $1-6 \% \mathrm{NaCl}$ ensured the criteria for identification of the probiotic bacteria. All the isolated bacteria showed excellent growth against low $\mathrm{pH}(3.0)$ and bile $(0.3 \%)$ in a 24 hour period of time. Isolated bacteria were tested for their antimicrobial activity against eight human and animal enteric pathogens and showed promising antimicrobial efficacy against the selective pathogens. Further research regarding, molecular characterization and identification of specific genes and proteins of interest through technological intervention may help to develop next generation bacteriocins and industrially important drug for human and animals.
\end{abstract}

(Key words: Lactic acid bacteria, probiotics, lactobacillus, antimicrobial activity)

\section{Introduction}

The word 'probiotic' comes from Latin word which means 'for life' (Ozen et al., 2015). The history of probiotics began when man started to consume fermented foods (Guarner et al., 2005). The meaning today we use comes from Fuller in 1989. He defined probiotic as "a live microbial supplement which affects host's health positively by improving its intestinal microbial balance". Probiotics are very challenging for the industrial applications. The lactic acid bacterial group basically consist of genetically and physiologically diverse group of gram positive, catalase negative, non-motile and non-pigmented (Hoque et al., 2010). Probiotics basically considered as GRAS microorganisms and have widespread use in different food and dairy industry for human and animals (Gharaei-Fathabad et al., 2011). Fermented food products such as yogurt is a good source of probiotics. Yogurt as a food is a good source of proteins, calcium, and vitamins. Basically, fermentation of yogurt involves the use of two of the laboratory species Lactobacillus bulgaricus and Streptococcus thermophiles in combination.

*Corresponding author: kmhossainbt@yahoo.com.au

Bang. J. Livs. Res. Special Vol. 21-25, 2018: P. 142-152, ISSN 1022-3851 
There are lots of studies have been conferred to search the potential health impact of probiotics. Probiotics modulate the immune system by increasing the secretion of IL- $1 \beta$, IL- 8 , and TNF- $\alpha$. Besides, probiotics exerts various important beneficial effects such as cancer suppressor (Wollowski et al., 2001), antimicrobial (Stiles, 1996; McAuliffe et al., 1999; Bredholt et al., 2001), antidiarrheal (Canani et al., 2007; Marteau et al., 2001), cholesterol reduction (Hlivak et al., 2005; Ataie-Jafari et al., 2009; Miremadi et al., 2014), anti-allergic (Toh et al., 2012; Abrahamsson et al., 2012; Kim et al., 2008 ) and antidiabetic (Asemi et al., 2013; Ejtahed et al., 2012; Calcinaro et al., 2005) effects.

One of the most important selection criteria of probiotics is antimicrobial activity against many pathogenic and undesirable microorganisms. Antimicrobial activity of different probiotic bacteria largely depends on their ability to produce some substances such as lactic acid, propanoic acid, acetic acid, carbon dioxide, hydrogen peroxide, low molecular weight antimicrobial substances and bacteriocins (Ouwehand and Vesterlund, 2004). Lactococcus lactis produce nisin which is active against a wide range of gram-positive bacteria and currently available in the market (Delves-Broughton, 1990).

Bacterial strains that are used as probiotics join with the food system with a journey to the lower intestinal tract via the mouth. Probiotic bacteria should be resistance to enzyme like lysozyme in the oral cavity in this food system. It is reported that time between the first entrance and release from stomach requires approximately 3 hours and by this time strains need to be resistant to the stressful condition in the stomach $(\mathrm{pH} 1.5-3)$ and upper intestine which contain bile (Chou and Weimer, 1999). Probiotic bacteria should reach to the lower intestinal tract and maintain themselves over there to show their sufficiency. Therefore, in this point of view, a major selection criterion for probiotic bacteria is resistant to acid and bile. Bile acids are synthesized in the liver from cholesterol and then sent to the gallbladder and secreted into the duodenum in the conjugated form. Some chemical modification such as deconjugation, dehydroxylation, dehydrogenation, and de-glucuronidation occur in the large intestine due to microbial action. Both of this conjugated and unconjugated bile acids show antimicrobial activity largely in E. coli species, Klebsiella spp. and Enterococcus spp. in vitro (Dunne et al., 1999).

Recently, the safety of this microorganisms is of very interest in the food industry. There are no established or validated testing criteria to determine the safety of microorganisms. This situation has created a requirement for regulation of probiotics (Wright, 2005). Considering the above facts in mind, the present study was undertaken to isolate and characterize the Lactobacillus spp. from yogurt from Rajshahi and Chittagong Divisions of Bangladesh.

\section{Materials and Methods}

\section{Collection of samples}

Twelve yogurt samples, six from each Division were collected from different dairy and sweet meat shops of Chittagong and Rajshahi Divisions of Bangladesh and carried in ice box to the concerned laboratory of Biotechnology and Genetic Engineering Discipline, Khulna University, Bangladesh. 
After collection, yogurt samples were stored aseptically at 4 in refrigerator to protect from deterioration and contamination.

\section{Isolation of probiotic bacteria from yogurt}

Pour plate technique was used for the isolation of bacteria. The samples were diluted to 7 times using sterile peptone water. One milliliter aliquots of the dilutions were plated on MRS (Man, Rogosa and Sharpe) agar ( $\mathrm{pH}$ 6.2). The plates were then incubated at $37^{\circ} \mathrm{C}$ for three days under anaerobic conditions. The using of this medium was aimed to isolate of lactic acid bacteria. Then the selected colonies were purified with streak plate techniques. The isolates were examined according to their colony morphology, gram reaction and catalase reaction. Gram positive and catalase negative bacilli and cocci were selected for further biochemical characterization.

\section{pH tolerance test}

It is considered that; the $\mathrm{pH}$ of human stomach is 1.5 to 3.5 . Therefore, resistance to $\mathrm{pH} 3$ is often used for in vitro assay to determine the resistance of stomach $\mathrm{pH}$. For this purpose, MRS broth medium was prepared with $\mathrm{pH} 3$ by using $5 \mathrm{~N} \mathrm{HCl}$. Then $20 \mu \mathrm{L}$ overnight grown bacterial cultures were inoculated in the $15 \mathrm{ml}$ broth medium. Afterwards, the test tubes were incubated at $37^{\circ} \mathrm{C}$ and absorbance were taken every four hours at $620 \mathrm{~nm}$ to determine the low $\mathrm{pH}$ tolerance and viability of the bacteria.

\section{Bile salt tolerance test}

It is believed that, the intestinal bile concentration of human is $0.3 \%$. Therefore, the experiment was conducted using this concentration. Sterilized 15ml MRS broth medium containing $0.3 \%$ bile was inoculated with $20 \mu \mathrm{L}$ overnight grown cultures. Then the tubes were incubated at $37^{\circ} \mathrm{C}$ and optical density were measured at $620 \mathrm{~nm}$ for every four hours for 24 hours through spectrophotometer.

\section{Antimicrobial activity test}

For the antimicrobial activity test, spot on lawn method was used. For this purpose, seven human and animal enteric pathogens were used as indicator organisms. After 24 hours incubation, active cultures of isolates were spotted on the MRS agar plate and again incubated for 24 hour at $37^{\circ} \mathrm{C}$. Then indicator organisms were inoculated in semi solid (1\%) agar and this inoculated agar was overlaid on the MRS agar plates. These agar plates were incubated according to the appropriate condition for indicator organisms. Inhibition zone diameters were measured after the incubation periods. Isolates which gave inhibition zone bigger than $1 \mathrm{~mm}$ was considered to have antimicrobial activity.

\section{$\mathrm{NaCl}$ tolerance test}

Isolates were examined for their tolerance against different $\mathrm{NaCl}$ concentrations. For this purpose, $2 \%, 4 \%, 6 \%$ and $8 \% \mathrm{NaCl}$ concentrations were used in MRS broth medium. The medium containing different $\mathrm{NaCl}$ concentrations were inoculated with $20 \mu \mathrm{L}$ overnight grown cultures in $15 \mathrm{ml}$ broth. Afterwards, the test tubes were incubated at $37^{\circ} \mathrm{C}$ and optical density was measured at $620 \mathrm{~nm}$ during every 4 hours to determine whether the isolates did tolerate to $\mathrm{NaCl}$ or not.

\section{Phenol tolerance test}

Four different concentrations of phenol $(0.1 \%, 0.2 \%, 0.3 \%$ and $0.4 \%)$ were used for this test. MRS broth containing these 
different concentrations of phenol were inoculated with $20 \mu \mathrm{L}$ overnight grown bacterial cultures and incubated at $37^{\circ} \mathrm{C}$. Then the optical density was measured at $620 \mathrm{~nm}$ for determining the tolerance against phenol.

\section{Coagulase test}

For coagulation test of the isolates, $10 \mathrm{ml}$ of milk sterilized at $121^{\circ} \mathrm{C}$ was taken in each test tubes. Then the milk was inoculated by $20 \mu \mathrm{L}$ overnight grown fresh cultures and incubated at $37^{\circ} \mathrm{C}$ for 24 hours. Coagulation of milk is the positive sign of the presence of LAB.

\section{Motility test}

The MIL semi broth medium was used for motility test of the isolates. For this purpose, the medium was sterilized at $121^{\circ} \mathrm{C}$ for 15 minutes. Then a single colony was taken and stabbed in every test tube containing $10 \mathrm{ml}$ of medium. The needle was kept in the same line as it was entered and as it was removed. Then the tubes were incubated at $37^{\circ} \mathrm{C}$ for 24 h. A positive motility test was indicated by a diffuse cloud of growth.

\section{Sugar fermentation test}

Isolates were characterized according to their fermentation pattern to different carbohydrate. Ten different carbohydrates viz. glucose, sucrose, lactose, xylose, raffinose, mannitol, galactose, maltose, sorbitol and fructose were used for sugar fermentation tests. At first sugar was dissolved in deionized water at a final concentration of $5 \%(\mathrm{w} / \mathrm{v})$. Sterilization of sugar solution was done by filter paper with diameter $0.22 \mu \mathrm{m}$. Sugar solutions were taken in sterilized screw capped test tube with phenol red (pH 6.5). Then sterilized Durham tube was placed inversely in each of the screw capped test tube. Overnight grown bacterial cells in MRS medium was harvested by centrifugation at $5000 \mathrm{rpm}$ for 10 minutes. Then bacterial cells were suspended in PBS buffer and $200 \mu \mathrm{L}$ of cell suspension was inoculated in each of the test tube. Incubation was done at $37^{\circ} \mathrm{C}$ for 24 hour and sugar fermentation was observed, as the change in color of the sugar solution from red to yellow by production of acid and production of gas in Durham tube.

\section{Results}

\section{pH tolerance test}

All the ten isolates showed tolerance in low $\mathrm{pH}$ about a period of 24 hours in 4-hour intervals. Isolates those were tolerance at $\mathrm{pH}$ 3.0 were selected for next steps. In the present experiment, ten isolates were resistance to low $\mathrm{pH}$ (Table 1).

\section{Bile tolerance test}

All the isolates showed tolerance against $0.3 \%$ bile salts. However, isolate SDV and MDG showed highest tolerance against $0.3 \%$ bile after four hours period. Each isolate showed highly tolerance against $0.3 \%$ bile after 24 hours period (Table 1).

\section{$\mathrm{NaCl}$ tolerance test}

All the isolates showed excellent growth against $2 \%$ and $4 \% \mathrm{NaCl}$ and moderate growth in $6 \% \mathrm{NaCl}$. However, no isolated bacteria showed significant growth against $8 \% \mathrm{NaCl}$ concentration after 24 hours period (Table 1).

\section{Phenol tolerance test}

All the isolates showed highly tolerance against this different phenol concentrations (Table 1). The highest growth rate was shown in $0.1 \%$ phenol concentration . 


\section{Antimicrobial sensitivity test}

The diameter of inhibition zones showed that, most of the isolates had antimicrobial activity (Figure 1). However, isolates, FF did not show inhibitory effect against Bacillus megaterium. Similarly, WF did not show antimicrobial activity against Salmonella paratyphi. Isolate MR and SK and BSB did not show any antimicrobial activity against Streptococcus aureus, Escherichia coli and Vibrio cholera, respectively. Rest of all isolates showed antimicrobial activity against all the pathogens.

Table 1. Biochemical and physiological characteristics of the isolated bacteria obtained from yogurt samples of Rajshahi and Chittagong Divisions of Bangladesh

\begin{tabular}{|c|c|c|c|c|c|c|c|c|c|c|c|c|c|c|c|}
\hline \multirow{2}{*}{$\begin{array}{l}\text { Name of } \\
\text { yogurt } \\
\text { samples }\end{array}$} & \multicolumn{15}{|c|}{ Bacterial Characteristics } \\
\hline & Shape & Gram & Catalase & Coagulase & Motility & $\mathrm{pH}$ & Bile salt & $\mathrm{NaC}$ & Tole & nce & & Phe & ool T & leran & \\
\hline $\mathrm{FF}$ & Bacilli & + & - & + & - & $\mathrm{pH} 3.0$ & $0.3 \%$ & $\begin{array}{l}2 \\
\%\end{array}$ & $\begin{array}{l}4 \\
\%\end{array}$ & $\begin{array}{l}6 \\
\%\end{array}$ & \begin{tabular}{|l|}
8 \\
$\%$
\end{tabular} & $\begin{array}{l}0.1 \\
\%\end{array}$ & $\begin{array}{l}0.2 \\
\%\end{array}$ & $\begin{array}{l}0.3 \\
\%\end{array}$ & $\begin{array}{l}0.4 \\
\%\end{array}$ \\
\hline WF & Bacilli & + & - & + & - & ++ & ++ & ++ & ++ & + & - & ++ & ++ & ++ & ++ \\
\hline MR & Bacilli & + & - & + & - & ++ & ++ & ++ & ++ & + & - & ++ & ++ & ++ & ++ \\
\hline SK & Bacilli & + & - & + & - & ++ & ++ & ++ & ++ & + & - & ++ & ++ & ++ & ++ \\
\hline KB & Bacilli & + & - & + & - & ++ & ++ & ++ & ++ & + & - & ++ & ++ & ++ & ++ \\
\hline DG & Bacilli & + & - & + & - & ++ & ++ & ++ & ++ & + & - & ++ & ++ & ++ & ++ \\
\hline BSB & Bacilli & + & - & + & - & ++ & ++ & ++ & ++ & + & - & ++ & ++ & ++ & ++ \\
\hline AS & Bacilli & + & - & + & - & ++ & ++ & ++ & ++ & + & - & ++ & ++ & ++ & ++ \\
\hline SDV & Bacilli & + & - & + & - & ++ & ++ & ++ & ++ & + & - & ++ & ++ & ++ & ++ \\
\hline MDG & Bacilli & + & - & + & - & ++ & ++ & ++ & ++ & + & - & ++ & ++ & ++ & ++ \\
\hline
\end{tabular}

["+" indicates tolerance, "++" indicates highly tolerance and s" indicates no tolerance against the conditions]

Table 2. Sugar fermentation pattern of the isolated bacteria isolated bacteria obtained from yogurt samples of Rajshahi and Chittagong Divisions of Bangladesh

\begin{tabular}{|c|c|c|c|c|c|c|c|c|c|c|}
\hline \multirow{2}{*}{$\begin{array}{l}\text { Name of } \\
\text { yogurt } \\
\text { samples }\end{array}$} & \multicolumn{10}{|c|}{ Name of Sugars } \\
\hline & $\begin{array}{l}0 \\
0 \\
0 \\
0 \\
0 \\
0\end{array}$ & 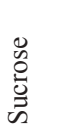 & 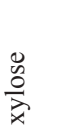 & 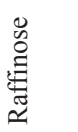 & $\begin{array}{l}0 \\
0 \\
0 \\
0 \\
0 \\
0 \\
01\end{array}$ & 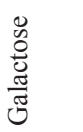 & $\begin{array}{l}0 \\
\stackrel{0}{0} \\
\frac{\pi}{\pi} \\
\Sigma\end{array}$ & 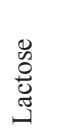 & 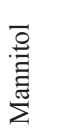 & 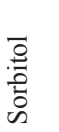 \\
\hline FF & + & + & + & + & + & + & + & + & - & - \\
\hline$\overline{\mathrm{WF}}$ & + & + & + & + & + & + & + & + & - & - \\
\hline MR & + & + & + & + & + & + & + & + & - & - \\
\hline SK & + & + & + & + & + & + & + & + & - & - \\
\hline KB & + & + & + & + & + & + & + & + & - & - \\
\hline DG & + & + & + & + & + & + & + & + & - & - \\
\hline$\overline{B S V}$ & + & + & + & + & + & + & + & + & - & - \\
\hline AS & + & + & + & + & + & + & + & + & - & - \\
\hline SDV & + & + & + & + & + & + & + & + & - & - \\
\hline MDG & + & + & + & + & + & + & + & + & - & - \\
\hline
\end{tabular}

["+" indicates tolerance, "++" indicates highly tolerance and " -" indicates no tolerance against the conditions] 


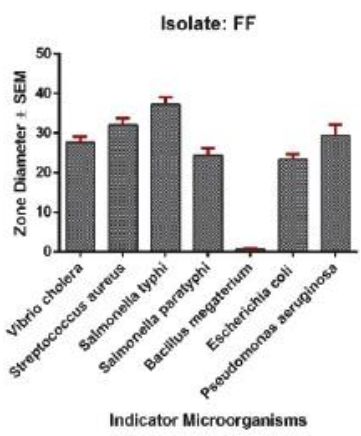

(a)

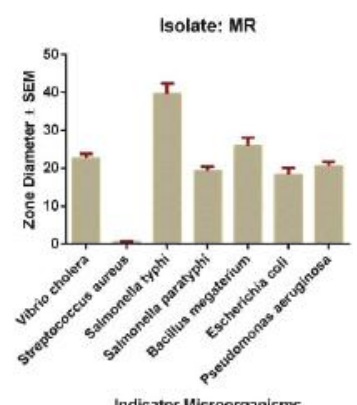

(e)

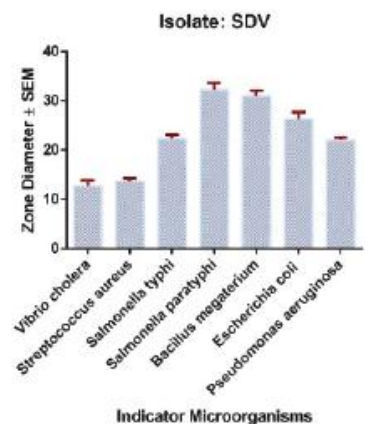

(i)

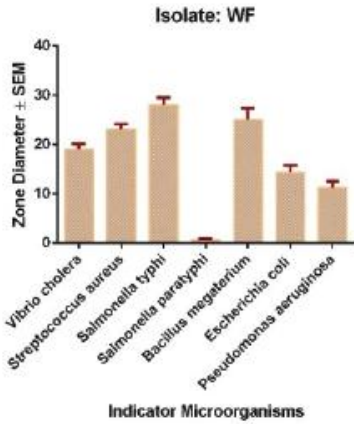

(b)

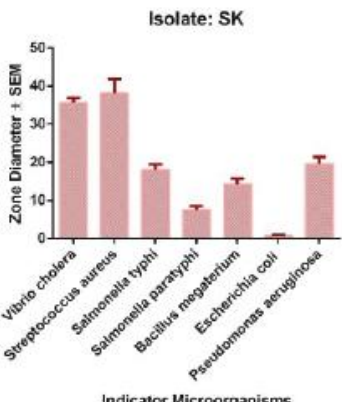

(f)

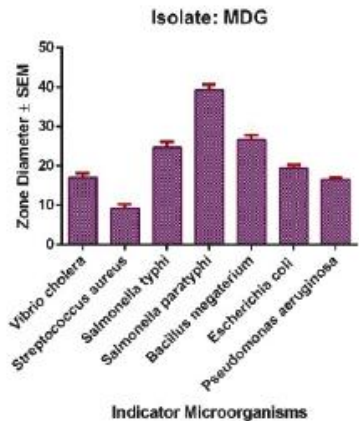

(j)

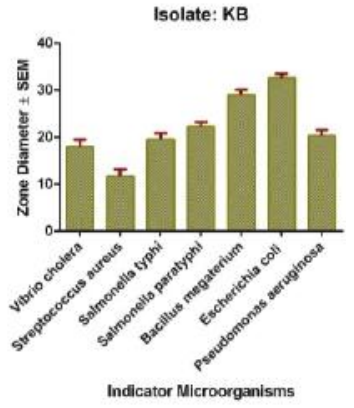

(c)

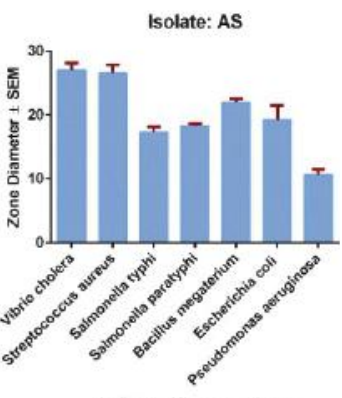

$(\mathrm{g})$

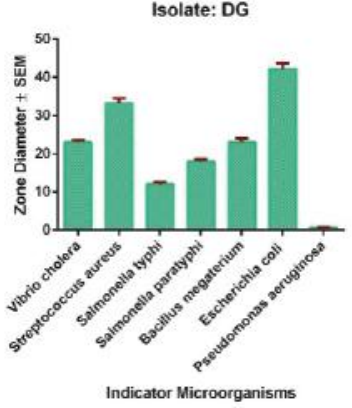

(d)

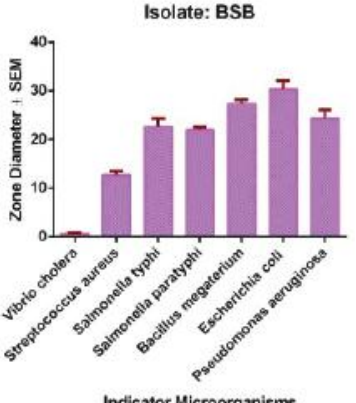

(h)

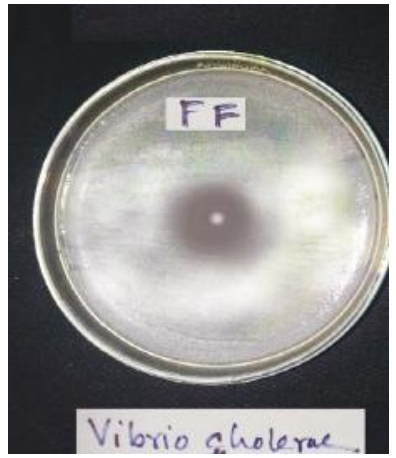

(h)

Figure 1: (a) antimicrobial activity of isolate FF, (b) antimicrobial activity of isolate WF, (c) antimicrobial activity of isolate $\mathrm{KB}$, (d) antimicrobial activity of isolate DG, (e) antimicrobial activity of isolate MR, (f) antimicrobial activity of isolate SK, (g) antimicrobial activity of isolate AS, (h) antimicrobial activity of isolate BSB, (i) antimicrobial activity of isolate SDV, (j) antimicrobial activity of isolate MDG and (h) antimicrobial activity testing of isolate FF against Vibrio cholerae.

\section{Discussion}

All the isolates showed probiotic characteristics which was five from Chittagong Division and another five from
Rajshahi Division. All of the isolates were isolated using the MRS media. Some of the components of MRS culture media such as sodium acetate, magnesium sulfate and tween-80 are known to act as special growth 
factors for the growth of lactic acid bacteria. Among them, tween-80 is a surfactant which facilitates the uptake of nutrients and sodium acetate, and ammonium citrate act as selective agents (DeMan et al., 1960). In the present study, the isolates were sub cultured six times and incubated anaerobically which might decrease the many fastidious unwanted microorganisms and favored the growth of lactic acid bacteria. From their colony morphology, physiological characteristics and biochemical characteristics (gram positive, catalase negative, non-motile, sugar fermentation pattern, resistance to inhibitory substances such as $\mathrm{pH} 2.2,0.3 \%$ bile acid, $0.1-0.4 \%$ phenol, $1-4 \% \mathrm{NaCl}$ ), all the ten isolates were considered probiotic bacteria. Hoque et al. (2010) identified Lactobacillus species from yogurt samples by observing their morphological characteristics and different biochemical characteristics such as gram positive, catalase negative, non-motile, sugar fermentation pattern, resistance to inhibitory substances such as $\mathrm{pH} 2.2,0.3 \%$ bile acid, $0.1-0.4 \%$ phenol, $1-10 \% \mathrm{NaCl}$. Microscopically the isolated bacteria were Gram positive, rod shaped, non-motile, catalase negative, coagulase positive. Therefore, the results of the present study were found similar to the findings of Hoque et al. (2010).

One of the major selection criteria of probiotics is resistance to low $\mathrm{pH}$. Chou and Weimer, 1999 reported that, probiotic bacteria needs to be resistance at low $\mathrm{pH}(\mathrm{pH}$ 1.5-3) while they pass from the stomach. Time between the first entrance and release from stomach requires approximately 3 hours and by this time probiotic must be viable. In most in vitro assays $\mathrm{pH} 3.0$ has been preferred cause, significant decrease in viability is often observed at $\mathrm{pH} 2.0$ or bellow
(Prasad, et al., 1998). All of the isolates obtained from present study, were more or less tolerant at $\mathrm{pH}$ 3.0. However, all of them showed resistance to low $\mathrm{pH}$ after 4 hour of period which needs to pass the stomach. Bao et al., 2010 isolated 90 strains of Lactobacillus fermentum, among them 35 strains showed tolerance against low $\mathrm{pH}$ which indicated the similarity with the findings of present study. Another similar research was conducted using 13 strains of Lactobacillus plantarum, among which 7 strains were highly tolerance against low $\mathrm{pH}$ (Cebeci and Gurakan, 2003). Lactobacillus acidophilus NIT isolated from infant feces, showed resistance to $\mathrm{pH} 2-4$ (Pan et al., 2009) which directly indicate the similarity with the findings of present study.

Isolates those were resistance to low $\mathrm{pH}$, were screened for tolerance against bile salt. It is considered that, mean bile concentration in the human gastrointestinal tract is $0.3 \%$ $\mathrm{w} / \mathrm{v}$ and the staying time is 4 hour (Prasad, et al. 1998). Bile tolerance is one of the most important attributes of probiotic lactic acid bacteria used as adjuncts because they enable them to survive, to grow and to perform their beneficial action in gastrointestinal tracts. Isolates that were resistant to low $\mathrm{pH}$ were screened for their ability to grow in $0.3 \%$ bile salts. The present experimental results showed that after 16 hour period of time all of the isolates were highly resistant to $0.3 \%$ bile salts. Maragkoudakis et al. (2006) screened 29 Lactobacillus strains for their tolerance against $0.3 \%$ bile salt and all of them showed resistance which indicates the similarity of the findings of the present study. Another research was conducted, and similar results was observed using 200 strains of Lactobacillus and Bifidobacterium and among them four highly resistant strains were 
selected. All of them showed tolerance against $0.5 \%$ bile even at $1 \%$. The strains were Lactobacillus rhamnosus HN001, Lactobacillus rhamnosus HN067, and Lactobacillus acidophilus HN017 and Bifidobacterium lactis HN019 (Prasad et al., 1998).

In the present study, the isolated lactic acid bacteria were assayed for their anti-microbial activity in vitro against eight human and animal enteric pathogens. Most of the isolated lactic acid bacteria showed their antimicrobial activity against the selected pathogens. The diameter of inhibition zones showed that most of the isolates have antimicrobial activity. It was reported that Lactobacillus reuteri resides in human GI tract and convert glycerol into reuterin which have potent antimicrobial activity against broad spectrum gram positive and gram negative bacteria (Spinler et al., 2008). In vitro antibacterial activity of selected strains belonging to probiotic genera, Lactobacillus was investigated by Tejero-Sariñena et al. (2012). In that study, agar spot test showed all the selected strains was antagonistic against Salmonella Typhimurium, Escherichia coli, Enterococcus faecalis, Staphylococcus aureusand, Clostridium difficile which indicates the similarity of findings of the present study. In another research, antimicrobial activity was examined for different Lactobacillus strains (L. reuteri, $L$. plantarum, L. mucosae, L. rossiae) isolated from pig faces against Salmonella typhimurium ATCC 27164, E. coli, C. perfringens $22 \mathrm{G}, \mathrm{S}$. aureus ATCC 25923, $B$. megaterium F6, L. innocua DSM 20649 and $B$. hyodysenteriae ATCC 27164. The study showed that all of the Lactobacillus strains had an inhibitory effect against all of the pathogens except B. hyodysenteriae ATCC
27164 (De-Angelis et al., 2006) which directly indicates the similarity of the present study. Another similar study was conducted where, four Lactobacillus strains (L. salivary CECT5713, L. gasseri CECT5714, L.gasseri CECT 5715 and L. fermentum CECT5716) was isolated from human milk and investigated the antimicrobial potentiality against pathogenic bacteria (Salmonella choleraesuis CECT4155, CECT409 and CECT443, Escherichia coli CECT439 and E. coli O157:H7 server CECT4076, Staphylococcus aureus CECT4013 and CECT9776, Listeria monocytogenes Scott A and the spoilage strain Clostridium tyrobutyricum CECT4011). All of the probiotic strains showed antagonistic effects against all of the pathogens but L. salivary CECT5713 showed best antimicrobial activity and highest protective effect against Salmonella choleraesuis CECT4155 (Olivares et al., 2005).

The result of the present study showed that, after 24-hours period of time all of the isolated bacteria were totally unaffected against $0.1-0.4 \%$ phenol. At $0.4 \%$ phenol, isolate AS and MR showed decreased growth after 4 hour period of time. Xanthopoulos et al. (2000) reported that $0.4 \%$ phenol may cause a bacteriostatic action in some microorganisms. In the present study, the isolated lactic acid bacteria were tested for tolerance against different $\mathrm{NaCl}$ concentration $(2 \%, 4 \%, 6 \%$ and $8 \%)$ in the MRS culture broth. All the isolates showed excellent growth against $1-4 \% \mathrm{NaCl}$ at 24 hour period of time. At the $8 \%$ level of $\mathrm{NaCl}$ concentration they did not show any significant growth at 24 hour period of time. Hoque et al. (2010) isolated Lactobacillus species from yogurt samples and reported that lactic acid bacteria grow excellently in $6 \% \mathrm{NaCl}$ which indicates the similarity of the 
findings of the present study.

\section{Conclusion}

Isolation and biochemical identification of lactic acid bacteria form yogurt samples from different regions of Bangladesh (Rajshahi and Chittagong Division) indicates a good source of probiotic bacteria. Ten isolated bacteria from the collected yogurt samples and considering their colony morphology and biochemical characteristics, the isolatesdid fulfill the criteria of Lactobacillus spp. They did exhibit good probiotic characteristics viz. low $\mathrm{pH}$ tolerance, bile tolerance and antimicrobial activity which might be used as a good probiotic candidate for development of different probiotic based drugs, therapeutic agents and can help to establish probiotic based dairy and other food industries for human, poultry and other animals.

\section{Acknowledgement}

The authors are grateful to the authority of National Agricultural Technology ProgramPhage II (NATP-2), Project Implementation Unit, Bangladesh Agricultural Research Council (BARC) for providing funding under Competitive Research Grant (CRG) by the World Bank.

\section{References}

Abrahamsson T.R., Jakobsson H.E., Andersson, A.F., Björkstén B, Engstrand L, Jenmalm M.C. 2012. Low diversity of the gut microbiota in infants with atopic eczema. Journal of allergy and clinical immunology, 129(2):434-440.

Asemi Z., Zare Z., Shakeri H., Sabihi S-s, Esmaillzadeh A. 2013. Effect of multispecies probiotic supplements on metabolic profiles,
hs-CRP, and oxidative stress in patients with type 2 diabetes. Annals of Nutrition and Metabolism, 63(1-2): 1-9.

Ataie-Jafari A., Larijani B., Majd HA., Tahbaz F. 2009. Cholesterol-lowering effect of probiotic yogurt in comparison with ordinary yogurt in mildly to moderately hypercholesterolemic subjects. Annals of Nutrition and Metabolism, 54(1): 22-27.

Bao Y., Zhang Y., Zhang Y., Liu Y., Wang S., Dong X, Wang Y, Zhang H. 2010. Screening of potential probiotic properties of Lactobacillus fermentum isolated from traditional dairy products. Food Control, 21(5): 695-701.

Bredholt S., Nesbakken T., Holck A. 2001. Industrial application of an antilisterial strain of Lactobacillus sakei as a protective culture and its effect on the sensory acceptability of cooked, sliced, vacuum-packaged meats. International journal of food microbiology, 66(3):191-196.

Calcinaro F., Dionisi S., Marinaro M., Candeloro P., Bonato V., Marzotti S., Corneli R., Ferretti E., Gulino A., Grasso F. 2005. Oral probiotic administration induces interleukin-10 production and prevents spontaneous autoimmune diabetes in the non-obese diabetic mouse. Diabetologia, 48(8): 1565-1575.

Canani R.B., Cirillo P., Terrin G., Cesarano L., Spagnuolo M.I., De Vincenzo A., Albano F., Passariello A., De Marco G., Manguso F. 2007. Probiotics for treatment of acute diarrhoea in children: randomised clinical trial of five different preparations. BMJ, 335(7615): 340.

Cebeci A. and Gürakan C., 2003. Properties of potential probiotic Lactobacillus plantarum strains. Food Microbiology, 20(5): 511-518.

Chou L.S. and Weimer B. 1999. Isolation and Characterization of Acid-and Bile-Tolerant Isolates from Strains of Lactobacillus acidophilus1. Journal of Dairy Science, 82(1):23-31.

De Angelis M., Siragusa S., Berloco M., Caputo L., Settanni L., Alfonsi G., Amerio M., Grandi 
A, Ragni A, Gobbetti M. 2006. Selection of potential probiotic lactobacilli from pig feces to be used as additives in pelleted feeding. Research in Microbiology, 157(8):792-801.

De Man J., Rogosa d., Sharpe M.E., 1960. A medium for the cultivation of lactobacilli. Journal of Applied Microbiology, 23(1): 130-135.

Delves-Broughton J., 1990. Nisin and its application as a food preservative. International Journal of Dairy Technology, 43(3):73-76.

Dunne C., Murphy L., Flynn S., O’Mahony L., O'Halloran S., Feeney M., Morrissey D., Thornton G., Fitzgerald G., Daly C., 1999. Probiotics: from myth to reality. Demonstration of functionality in animal models of disease and in human clinical trials. In: Lactic Acid Bacteria: Genetics, Metabolism and Applications. Springer, 279-292.

Ejtahed H.S., Mohtadi-Nia J., Homayouni-Rad A., Niafar M., Asghari-Jafarabadi M,. Mofid V., 2012. Probiotic yogurt improves antioxidant status in type 2 diabetic patients. Nutrition, 28(5): 539-543.

Gharaei-Fathabad E., Eslamifar M., 2011. Isolation and applications of one strain of Lactobacillus paraplantarum from tea leaves (Camellia sinensis). Am J Food Technol, 6(5): 429-434.

Guarner F., Perdigon G., Corthier G., Salminen S., Koletzko B., Morelli L., 2005. Should yoghurt cultures be considered probiotic? British Journal of Nutrition,93(6):783-786.

Hlivak P., Odraska J., Ferencik M., Ebringer L., Jahnova E., Mikes Z., 2005. One-year application of probiotic strain Enterococcus faecium M-74 decreases serum cholesterol levels. BratislLekListy, 106(2):67-72.

Hoque M., Akter F., Hossain K., Rahman M., Billah M., Islam K., 2010. Isolation, identification and analysis of probiotic properties of Lactobacillus spp. from selective regional yoghurts. World Journal of Dairy \& Food Sciences, 5(1):39-46.
Kim J.Y., Choi Y.O., Ji G.E., 2008. Effect of oral probiotics (Bifidobacterium lactis AD011 and Lactobacillus acidophilus AD031) administration on ovalbumin-induced food allergy mouse model. J. MicrobiolBiotechnol, 18(8): 13931400 .

Maragkoudakis P. A., Miaris C., Rojez P., Manalis N., Magkanari F., Kalantzopoulos G., Tsakalidou E., 2006. Production of traditional Greek yoghurt using Lactobacillus strains with probiotic potential as starter adjuncts. International dairy journal, 16(1):52-60.

Marteau P.R., VreseM.D., Cellier C.J., Schrezenmeir J., 2001. Protection from gastrointestinal diseases with the use of probiotics. The American journal of clinical nutrition, 73(2): 430-436.

McAuliffe O., Hill C., Ross R., 1999. Inhibition of Listeria monocytogenes in cottage cheese manufactured with a lacticin 3147-producing starter culture. Journal of Applied Microbiology, 86(2):251-256.

Miremadi F., Ayyash M., Sherkat F., Stojanovska L., 2014. Cholesterol reduction mechanisms and fatty acid composition of cellular membranes of probiotic Lactobacilli and Bifidobacteria. Journal of Functional Foods, 9;295-305.

Olivares M., Díaz-Ropero M.P., Gómez N., Lara-Villoslada F., Sierra S., Maldonado J.A, Martín R., Rodríguez J.M., Xaus J., 2005. The consumption of two new probiotic strains, Lactobacillus gasseri CECT 5714 and Lactobacillus coryniformis CECT 5711, boosts the immune system of healthy humans. International microbiology, 9(1):47-52.

Ouwehand A.C., Vesterlund S., 2004. Antimicrobial components from lactic acid bacteria. Food science and technology-new york-marcel dekker, 139:375-396.

Ozen M., Kocabas Sandal G., Dinleyici E.C., 2015. Probiotics for the prevention of pediatric upper respiratory tract infections: a systematic review. Expert opinion on biological therapy, 
15(1);9-20.

Pan X., Chen F., Wu T., Tang H., Zhao Z., 2009. The acid, bile tolerance and antimicrobial property of Lactobacillus acidophilus NIT. Food Control, 20(6):598-602.

Prasad J., Gill H., Smart J., Gopal P.K., 1998. Selection and characterisation of Lactobacillus and Bifidobacterium strains for use as probiotics. International Dairy Journal, 8(12): 993-1002.

Spinler J.K., Taweechotipatr M., Rognerud C.L., Ou C.N, Tumwasorn S, Versalovic J. 2008. Human-derived probiotic Lactobacillus reuteri demonstrate antimicrobial activities targeting diverse enteric bacterial pathogens. Anaerobe, 14(3):166-171.

Stiles M.E., 1996. Biopreservation by lactic acid bacteria. Antonie van leeuwenhoek, 70(2-4): 331-345.

Tejero-Sariñena S., Barlow J., Costabile A., Gibson G.R., Rowland I., 2012. In vitro evaluation of the antimicrobial activity of a range of probiotics against pathogens: evidence for the effects of organic acids. Anaerobe, 18(5):530-538.

Toh Z.Q., Anzela A., Tang M.L., Licciardi P.V., 2012. Probiotic therapy as a novel approach for allergic disease. Frontiers in pharmacology, $3 ; 171$.

Wollowski I., Rechkemmer G., Pool-Zobel BL., 2001. Protective role of probiotics and prebiotics in colon cancer. The American journal of clinical nutrition, 73(2):451-455.

Wright Av., 2005. Regulating the safety of probiotics-The European approach. Current pharmaceutical design, 11(1):17-23.

Xanthopoulos V., Litopoulou-Tzanetaki E., Tzanetakis N., 2000. Characterization of Lactobacillus isolates from infant faeces as dietary adjuncts. Food Microbiology, 17(2): 205-215. 